

\title{
Financial Literacy and Inclusion Analysis of The Community of Pulau Seribu (A Case Study on The Limitations of Banking Financial Services in The Pulau Seribu)
}

\author{
Erni Prasetiyani ${ }^{1}$, Ai Nety Sumidartini ${ }^{2}$, Achmad Barlian $^{3}$ \\ Institut Ilmu Sosial dan Manajemen STIAMI \\ ${ }^{1}$ Correspondent: erni@stiami.ac.id
}

\author{
Received : August 08, 2021 \\ Accepted : August 25, 2021 \\ Published : October 31, 2021
}

Citation: Prasetiyani, E., Sumidartini, A.N, Barlian, A. (2021). Financial Literacy And Inclusion Analysis Of The Community Of Pulau Seribu (A Case Study On The Limitations Of Banking Financial Services In The Pulau Seribu). Ilomata International Journal of Tax \& Accounting 2(4),255-261. https://doi.org/10.52728/ijtc.v2i4.373

\begin{abstract}
The progress of a region can be measured by the level of financial literacy of its population and financial inclusion. DKI Jakarta is in the top financial ranking for literacy and inclusion, but it is inversely proportional to the Pulau Seribu region. This research is a qualitative research with the technique of obtaining data through in-depth interviews with residents in the Pulau Seribu. The results are processed with a Strength Weakness Opportunity Threat (SWOT) analysis to produce a map of the strengths, weaknesses, opportunities and threats that exist in the Pulau Seribu region. With the SWOT condition in the region, it is hoped that the policy makers, namely the Otoritas Jasa Keuangan (OJK), the DKI Jakarta Regional Government and the community themselves are able to synergize in formulating strategies to accelerate the backwardness of the Pulau Seribu with DKI Jakarta.
\end{abstract}

Keywords: Financial Literacy, Financial Inclusion, Strength Weakness Opportunity Threat (SWOT) and the Otoritas Jasa Keuangan(OJK)

\section{INTRODUCTION}

Financial literacy in the industrial era has become a hot issue for a country's economic progress. Some countries experienced a significant increase while others experienced stagnation and even did not experience significant changes. Countries with the highest acceleration of financial literacy are China and India which occupy a financial literacy level of $87 \%$ while Indonesia is only at $34 \%$, Russia and Africa are at the level of $82 \%$ (Shandy, 2021).

In a study about financial literacy in South Africa showed those gender, age, language, race and income levels do have an impact on the level of financial literacy (de Clercq \& Venter, 2009). In other study for Muslim community in USA, even religion have an impact on the level of financial literacy (Zinser, 2019). The newest study in Portugal, shows that the financial literacy scale presents a tri-factor structure with adequate validity and reliability levels. The three obtained factors are designated 1-2-year financial planning and goals, long-term saving and taste for numeric

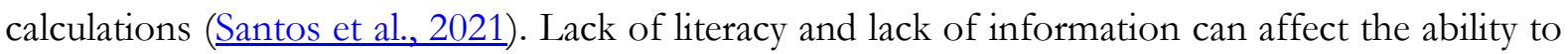
save and secure a comfortable retirement. Few individuals rely on the help of financial advisors, 
Financial Literacy and Inclusion Analysis of The Community of Pulau Seribu (A Case Study on The Limitations of Banking Financial Services in The Pulau Seribu)

Prasetiyani, Sumidartini, Barlian

and ignorance about basic financial concepts can be linked to a lack of retirement planning and lack of wealth (Sarpong-Kumankoma, 2021).

A study in Indonesia show that Financial Literacy has a positive effect on Access to Finance and Growth of MSMEs, and Access to Finance also has a positive effect on Growth of MSMEs SSusan, 2020). The purpose of financial literacy is to create better economic decisions through citizens who have adequate information and knowledge and also to improve household welfare both individually and in groups (Nugraha, 2018). Financial literacy is able to move economic actors to carry out financial planning. Financial planning according to the Otoritas Jasa Keuangan $(\mathrm{OJK})$ is how to live a simple current life in accordance with financial conditions and prepare for a better and more advanced future (Suryani \& Ramadhan, 2017).

The demographics of financial literacy in Indonesia in 2019 based on the OJK survey

Figure 1. Indonesia's 2019 financial literacy demographics

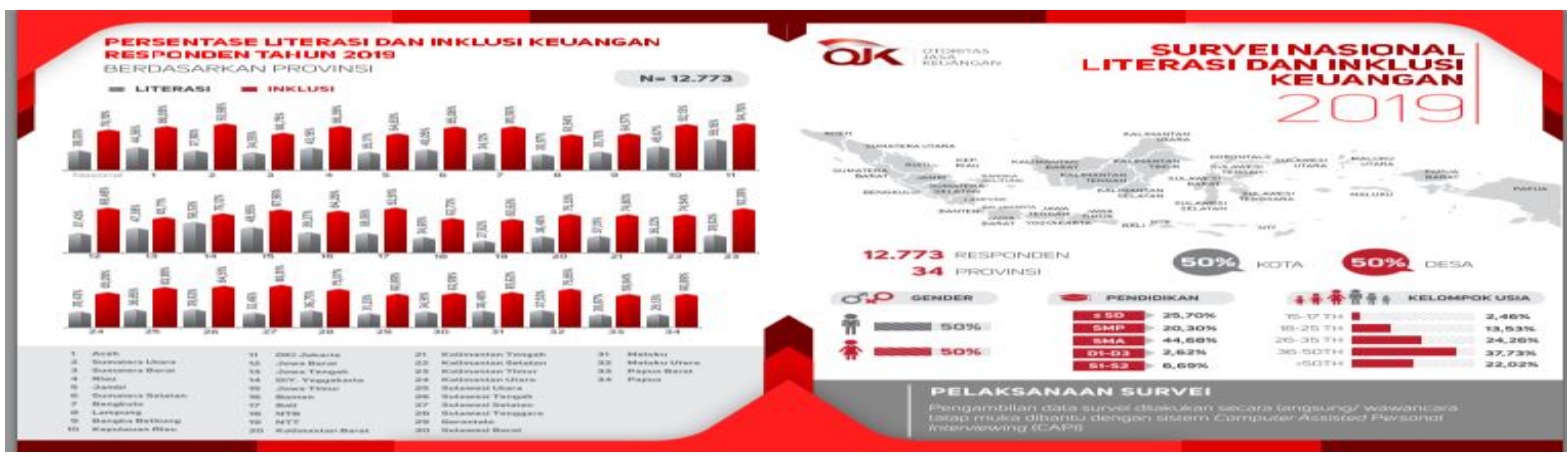

Source: Otoritas Jasa Keuangan Survey Report 2019

The OJK survey shows that the highest position of financial literacy is occupied by the province of DKI Jakarta at $59.16 \%$ and the lowest position in the province of Nusa Tenggara Timur (NTT) at $27.62 \%$ (Jasa Keuangan, 2019)

The existence of a gap between the Pulau Seribu and the mainland DKI Jakarta shows that the development is not evenly distributed economically or commonly referred to as the development economy in which a country aims to improve the welfare of its people. Development economics is the part of economics that deals with the economic aspects of the development process in lowincome countries. Economic development does not only develop its economic development, economic growth and structural changes but also in increasing the potential of the mass population, such as through health, education and the work environment, both through the public sector and the private sector (private sector). The definition of economic development according to Indonesian economist Sadono Sukirno "development economy is the process of increasing income or per capita income of a country by processing economic potential into real form" (Sukirno, 2006).

In order to harmonize the development economy and a sustainable financial system to form a quality society in terms of human resources and economic aspects, OJK has issued a roadmap for sustainable finance (sustainable finance) which is defined as comprehensive support from the financial services industry for sustainable growth resulting from harmony. between economic, social and environmental interests as stated in the Medium Term Development Plan (RPJMn) dated 5 December 2014 and published the 2015-2019 Sustainable Finance Roadmap (Roadmap for Suistainable Finance in Indonesia, 2015). 
Financial Literacy and Inclusion Analysis of The Community of Pulau Seribu (A Case Study on The Limitations of Banking Financial Services in The Pulau Seribu)

Prasetiyani, Sumidartini, Barlian

The problems DKI Jakarta is as the top rank in financial literacy is an indicator of the high level of welfare of its population, in addition to high financial literacy, DKI Jakarta's financial inclusion also ranks first at $94.76 \%$ while NTT province lasts at $60.63 \%$, however, the DKI Jakarta area, which is divided into two regions, namely mainland DKI Jakarta and the Pulau Seribu, has resulted in uneven distribution of financial inclusion and experienced very different gaps. In terms of financial literacy, the people of the Pulau Seribu are sufficient, but in terms of financial inclusion, their access is not wide open to get it.

The researchers used analysis Strength Weakness Opportunity and Threat or SWOT is a strategy that can be optimized by combining strengths and opportunities, but at the same time there are also weaknesses and threats that must be minimized (Abadi et al., 2020), to measure the strengths and weaknesses of Pulau Seribu in utilizing financial literacy and empowering financial inclusion as a strategy for the potency welfare of the community's economy,. Each of these factors can be described as follows:

1. Strength, namely the advantages possessed by the resources owned by the organization, which can be used by factors that can handle threats.

2. Weaknesses, namely deficiencies in resources that are difficult to use to deal with opportunities and threats.

3. Opportunity, namely the external condition of resources that have the potential to be profitable.

4. Threat is an external condition that has the potential to cause problems and difficulties.

Table 2. SWOT Matrix

\begin{tabular}{llll}
\hline & $\begin{array}{l}\text { Strength }- \text { S (Strength) } \\
\text { List of strengths }\end{array}$ & $\begin{array}{l}\text { Weaknesses-W } \\
\text { (Weaknesses) List of } \\
\text { weaknesses }\end{array}$ \\
\hline $\begin{array}{l}\text { Opportunity - O } \\
\text { (Opportunity) }\end{array}$ & $\begin{array}{l}\text { SO Strategy } \\
\text { List of opportunities }\end{array}$ & $\begin{array}{l}\text { WO Strategy } \\
\text { of opportunities }\end{array}$ & $\begin{array}{l}\text { Overcome weaknesses by } \\
\text { taking advantage } \\
\text { opportunities }\end{array}$ \\
\hline $\begin{array}{l}\text { Threats - T (Threats) } \\
\text { Threat list }\end{array}$ & $\begin{array}{l}\text { ST strategy } \\
\text { Use power to avoid threats }\end{array}$ & $\begin{array}{l}\text { Minimize weaknesses and } \\
\text { avoid threats. }\end{array}$ \\
\hline
\end{tabular}

The table above is a summary of the SWOT analysis and the combination strategy between the pros and cons of various conditions (Prasetiyani, 2006)

\section{METHOD}

The research was conducted using qualitative methods with data collection techniques through indepth interviews. Interviews with the main informants are those who are directly involved in the social interactions studied and additional informants are those who can provide information even though they are not directly involved in social interactions (Rony, 2017). Informants major is they have access and always associated with bank in financial interaction as public servants and MSMEs while additional informants were informants scanty associated with banks and used in comparison course. The type of interview conducted is a semi-structured interview which is a free interview where the researcher still makes special guidelines. 
Financial Literacy and Inclusion Analysis of The Community of Pulau Seribu (A Case Study on The Limitations of Banking Financial Services in The Pulau Seribu)

Prasetiyani, Sumidartini, Barlian

The interview is in the form of a closed questionnaire where the researcher gives answer choices about financial literacy, financial inclusion and the business and financial conditions of the respondent or informant. The following are the things question by the researchers:

Table 3. Question Aspect

No.

Question Aspect

\section{Context}

1. Knowledge of financial and banking To obtain information on community products representatives consisting of crossprofessionals

2. Access to banking and credit To obtain data on banking facilities in the Pulau Seribu and access to credit from banks or Non-Bank Financial Institutions that have been received so far

3. Business and financial conditions

To obtain data on how business and financial conditions are with access to banking and credit that has been received

\section{RESULT AND DISCUSSION}

There were 3 (three) residents of the Pulau Seribu from different backgrounds who underwent indepth interviews with a team of lecturers whose questions included financial literacy, financial inclusion and business and finance where the informants consisted of Micro, Small and Medium Enterprises (MSMEs), Civil Servants(civil servants), fishermen.

The main questions are divided into 3 parts, namely (1). Financial literacy (2). Access to Banking and Credit (3). Business and Finance. Following are the results of written interviews with 3 (three) residents of the Pulau Seribu with various professions.

\begin{tabular}{|c|c|c|c|}
\hline No. & Financial Literacy & Access Banking \& Credit & $\begin{array}{l}\text { Business and Financial } \\
\text { Condition }\end{array}$ \\
\hline $\begin{array}{l}\text { informant 1, } \\
\text { Woman } \\
\text { Civil Servant } \\
\text { Teacher }\end{array}$ & $\begin{array}{l}\text { Knowledge of banking } \\
\text { functions and benefits is } \\
\text { quite good. Utilize BRI- } \\
\text { link for daily financial } \\
\text { transactions. }\end{array}$ & $\begin{array}{l}\text { Feeling unsatisfied with access to } \\
\text { banking in their area because they } \\
\text { are only served by mobile banks } \\
\text { whose arrivals are uncertain. } \\
\text { Informant } 1 \text { does not have credit at } \\
\text { a bank and has never borrowed } \\
\text { money from a bank. }\end{array}$ & $\begin{array}{l}\text { Informant } 1 \text { does not have a } \\
\text { business and financial } \\
\text { condition is quite good, } \\
\text { income comes from salary as } \\
\text { a teacher }\end{array}$ \\
\hline $\begin{array}{l}\text { informant 2, } \\
\text { Man } \\
\text { Fisherman }\end{array}$ & $\begin{array}{l}\text { Knowledge of banking } \\
\text { functions and benefits is } \\
\text { good. Utilize BRI-link for } \\
\text { daily } \\
\text { transactions. }\end{array}$ & $\begin{array}{l}\text { Feeling unsatisfied with the } \\
\text { condition of the mobile bank } \\
\text { model. According to him, there } \\
\text { should be a bank at the district } \\
\text { level. Informant } 2 \text { has no credit and } \\
\text { has never used credit from a bank } \\
\text { for his fishing business. Have never } \\
\text { received a People's Business Credit } \\
\text { and really need the credit. }\end{array}$ & $\begin{array}{l}\text { For now, the income is only } \\
\text { as a fisherman. Financial } \\
\text { management has separated } \\
\text { money for family needs and } \\
\text { business interests as } \\
\text { fishermen. Don't have books } \\
\text { yet because you don't know } \\
\text { how to get started. Turnover } \\
\text { IDR } 1 \text { million- IDR } 6 \text { million }\end{array}$ \\
\hline $\begin{array}{l}\text { Informant } 3 \text {, } \\
\text { Male } \\
\text { Fisherman } \\
\text { and collector } \\
\text { of used } \\
\text { goods }\end{array}$ & $\begin{array}{l}\text { Knowledge of banking } \\
\text { functions and benefits is } \\
\text { good. Utilize BRI-link for } \\
\text { daily financial } \\
\text { transactions. }\end{array}$ & $\begin{array}{l}\text { Feeling enough with the mobile } \\
\text { bank model. As a fisherman and } \\
\text { collector of used goods, he uses } \\
\text { savings as business capital. Has no } \\
\text { credit and urgently needs People's } \\
\text { Business Credit. }\end{array}$ & $\begin{array}{l}\text { Income comes from } \\
\text { fishermen and collectors. } \\
\text { The monthly income is more } \\
\text { than IDR } 6 \text { million per } \\
\text { month. }\end{array}$ \\
\hline
\end{tabular}


Financial Literacy and Inclusion Analysis of The Community of Pulau Seribu (A Case Study on The Limitations of Banking Financial Services in The Pulau Seribu)

Prasetiyani, Sumidartini, Barlian

SWOT analysis of financial literacy and inclusion in the Thousand Islands

Opportunity -
(Opportunity)
- Community empowerment is
widely open to be more
advanced skillfully and
economically
- The marine tourism sector
can be developed more
optimally open banking
- Wide op
opportunities for expansion in
order to create an equitable
development economy on this
island

Opportunity

- Community empowerment is widely open to be more advanced skillfully and economically

- The marine tourism sector can be developed more optimally

opportunities for ex order to create an equitable development economy on this island
Threats - T (Threats)

- Economic access in terms of banking and credit which is very limited will result in slow progress both in terms of human resources and local revenue-Sustainable tourism will be very difficult to realize because it faces quite heavy competition where development on land is currently faster, making it easier to reach the destination faster and affordable, for example, the Jakarta-Surabaya toll road is only taken 9 hours - If this is not handled quickly, there will be an opportunity for an increase in the number of poor people in DKI Jakarta province

\section{Strength - S (Strength)}

- Pulau Seribu is a tourist destination

for residents of Jakarta and its surroundings

- Area close to the capital city of DKI

Jakarta, the most developed city in Indonesia \}

- The population is multi-ethnic

- The community $56.79 \%$ are

fishermen

- The home industry for breadfruit chips has become an icon for Pulau Seribu souvenirs.

- Financial literacy is quite good

\section{SO Strategy}

As a part of Jakarta, the Pulau Seribu should have broad opportunities to be equal economically, socially and educationally so that the people there can develop optimally which in turn can create jobs and increase the income of local residents with all the strengths and opportunities that exist.
Weaknesses - W (Weaknesses)

- Pulau Seribu has many

islands, each of which is inhabited

- Breadfruit chips home

industry is still managed conventionally

- The average education is only up to high school

- Limited access to banking and access to credit/ no financial inclusion

- Development gap with mainland Jakarta WO Strategy

The existence of a home industry that is still managed conventionally and has not been touched by technology will open up opportunities for the transfer of food technology which will create a variety of other Pulau Seribu culinary delights such as culinary from marine biota or souvenir products. For banking, there must be new innovations to manage this area because there are residents who live in small islands while currently banking is still served by mobile banks. The opening of bank branch offices, both stateowned and private banks, needs to be studied by mobilizing funds to transport using special transportation

\section{WT Strategy}

If the economic development strategy is not quickly updated, the economy in this region will gradually experience a slowdown and have the potential to create a poor community. To anticipate this, a movement of the banking literacy community is needed so that they become a bankable society. The financial literacy of the people in this area is quite good but the same opportunities as DKI Jakarta are not widely given by policy makers.

With the demoraphics of education up to university level which is still low and the absence of access to banking, it shows that the level of welfare of the population in this area is still low. The role of OJK as an authority that has a financial road map for all the nation's children is to play a more active role in mobilizing and creating a younger generation who are more technology literate and more familiar with the financial industry so that weaknesses and threats can be minimized or even eliminated. 
Financial Literacy and Inclusion Analysis of The Community of Pulau Seribu (A Case Study on The Limitations of Banking Financial Services in The Pulau Seribu)

Prasetiyani, Sumidartini, Barlian

\section{CONCLUSION}

Financial literacy and financial inclusion are not always directly proportional. For example, in the Pulau Seribu, citizens are literate enough to understand financial knowledge but lack the opportunity to get access to finance (inclusion). This island group is part of the DKI Jakarta area but is very contrary to economic development so that the facilities, pleasures and conveniences that are available in DKI Jakarta are not fully enjoyed by residents of this area. It takes a breakthrough, good faith and a very innovative strategy to lift this area into little Jakarta. The synergy between the DKI Jakarta Regional Government, OJK and the local community will determine the realization of a sustainable finance roadmap which was initiated and became the OJK program.

\section{REFERENCE}

Abadi, M. D., Lailiyah, E. H., \& Kartikasari, E. D. (2020). Analisis SWOT Fintech Syariah Dalam Menciptakan Keuangan Inklusif di Indonesia (Studi Kasus 3 Bank Syariah di Lamongan). Jesya Jurnal Ekonomi \& Ekonomi Syariah), 4(1), 178-188. https://doi.org/10.36778/jesya.v4i1.298

de Clercq, B., \& Venter, J. M. P. (2009). Factors influencing a prospective chartered accountant's level of financial literacy: an exploratory study. Meditari Accountancy Research, 17(2), 47-60. https://doi.org/10.1108/10222529200900011

Roadmap for Suistable Finance in Indonesia, (2015).

Jasa Keuangan, O. (2019). Survei Nasional Literasi dan Inklusi Kenangan 2019. Jasa Keuangan, Otoritas. https://www.ojk.go.id/id/berita-dan-kegiatan/publikasi/Pages/Survei-NasionalLiterasi-dan-Inklusi-Keuangan-2019.aspx

Nugraha, U. (2018). Strategy to Accelerate Financial Literacy Rate in Indonesia: Best Practices from Selected Countries. Jurnal Perencanaan Pembangunan: The Indonesian Journal of Development Planning, 2(1). https://doi.org/10.36574/jpp.v2i1.33

Prasetiyani, E. (2006). Analysis of the Influence of the Cash Management Service Strategy on Fee Based Income at Bank X.

Rony, Z. T. (2017). Siap Fokus, Siap Menulis Skripsi, Tesis, Disertasi (Jurus Mudab Gunakan Metode Kualitatif Tipe Studi Kasus) (Issue November 2017).

Santos, E. M. M., Tavares, V. C., Ratten, V., \& Tavares, F. O. (2021). The profile of the Portuguese regarding the perception of financial literacy. Managerial Finance, abead-of- $p$ (ahead-of-print). https://doi.org/10.1108/MF-05-2021-0210

Sarpong-Kumankoma, E. (2021). Financial literacy and retirement planning in Ghana. Review of Behavioral Finance, ahead-of-p(ahead-of-print). https://doi.org/10.1108/RBF-05-2020-0110

Shandy, K. F. (2021). Duh, Tingkat Melek Keuangan Kita Kalah Jauh oleh China dan India. Sindo News, 1. https://ekbis.sindonews.com/read/302262/178/duh-tingkat-melek-keuangan-kitakalah-jauh-oleh-china-dan-india-1610690476

Sukirno, S. (2006). Ekonomi Pembangunan : Proses, Masalab dan Dasar Kebijakan (2nd ed.). Kencana.

Suryani, S., \& Ramadhan, S. (2017). Analisis Literasi Keuangan pada Pelaku Usaha Mikro di Kota Pekanbaru. Journal of Economic, Bussines and Accounting (COSTING), 1(1), 12-22. https://doi.org/10.31539/costing.v1i1.67 
Financial Literacy and Inclusion Analysis of The Community of Pulau Seribu (A Case Study on The Limitations of Banking Financial Services in The Pulau Seribu)

Prasetiyani, Sumidartini, Barlian

Susan, M. (2020). Financial Literacy and Growth of Micro, Small, and Medium Enterprises in West Java, Indonesia (pp. 39-48). https://doi.org/10.1108/S1571-038620200000027004

Zinser, B. A. (2019). Retail Islamic banking and financial services: Determinants of use by Muslims in the USA. Journal of Islamic Marketing, 10(1), 168-190. https://doi.org/10.1108/JIMA-072017-0074 